University of Chicago Law School

Chicago Unbound

Journal Articles

Faculty Scholarship

1995

\title{
The Status-Production Sideshow: Why the Antidiscrimination Laws Are Still a Mistake
}

Richard A. Epstein

Follow this and additional works at: https://chicagounbound.uchicago.edu/journal_articles

Part of the Law Commons

\section{Recommended Citation}

Richard A. Epstein, "The Status-Production Sideshow: Why the Antidiscrimination Laws Are Still a Mistake," 108 Harvard Law Review 1085 (1995).

This Article is brought to you for free and open access by the Faculty Scholarship at Chicago Unbound. It has been accepted for inclusion in Journal Articles by an authorized administrator of Chicago Unbound. For more information, please contact unbound@law.uchicago.edu. 


\title{
THE STATUS-PRODUCTION SIDESHOW: WHY THE ANTIDISCRIMINATION LAWS ARE STILL A MISTAKE
}

\author{
Richard A. Epstein*
}

\section{INTRODUCTION}

The civil rights movement today is beset by frustration, failure, and division. This categorical statement is not meant to draw attention to the day-to-day troubles that might embarrass any large-scale social or political movement. Take, for example, the position of the NAACP. ${ }^{1}$ The recent dismissal of its executive director, Benjamin Chavis, was no doubt attributable in part to his settlement of Mary Stansel's lawsuit for sexual harassment and to the large financial deficits that accumulated under his administration. ${ }^{2}$ And his dismissal surely had to do with his policies to radicalize what had become a stolid, mainstream organization. But the long-term difficulties of the NAACP (as with other civil rights organizations) surely cut deeper than this. The policies of the NAACP worked best when targeted at the obvious evils of Jim Crow and segregation. ${ }^{3}$ These policies do not work well in the more complex and intractable disputes that are the hallmark of the last generation. No amount of agreement on the evils of Jim Crow can conceal the strong levels of disagreement about whether to pursue a policy of affirmative action and if so in what

* James Parker Hall Distinguished Service Professor of Law, The University of Chicago. Isaac Barchas provided his usual insightful research assistance.

1 For a full account that makes this diagnosis of the situation but offers solutions that are at variance with my own, see Benjamin Wittes, End of the Rainbow, New Republic, Dec. 26, I994, at 13 .

2 See Sylvester Monroe, After the Revolution, Trme, Aug. 29, 1994, at 40. Benjamin Chavis was succeeded at the NAACP by Dr. William F. Gibson. The NAACP subsequently ousted Gibson and elected Myrlie Evers-Williams as the organization's chair. Gibson was criticized for "lavish spending" and allegedly misappropriating NAACP funds for himself. Steven A. Holmes, Gibson Ousted As the Leader of N.A.A.C.P., N.Y. TmMES, Feb. 19, 1995, at AI, A35.

3 As one commentator noted:

At bottom, the NAACP never progressed beyond the era when race issues were simple matters of civil rights. During the 1950 s and ' 605 , the organization helped design and carry out a strategy of mass action, protests, lobbying and marches to destroy segregation. This strategy, based on the stark, morally unambiguous reality of racial oppression, reflected a view of local government as the instrument of civil rights abuse and the federal government as its remedy. The approach targeted legalized segregation, and Jim Crow melted in a decade, but it translated poorly into the next era.

Wittes, supra note I, at I4. The same sentiment is expressed in Monroe's article: "Of what use is the N.A.A.C.P. - or any other traditional black civil-rights organizations - now that most legal barriers to housing, education and the political arena have been removed?" Monroe, supra note 2, at 40 . 
fashion. ${ }^{4}$ Universal agreement on the right of all Americans to vote regardless of color offers little guidance on the issue whether districts should be shaped in order to maximize the number of black representatives in Congress or in state legislatures. ${ }^{5}$ Widespread agreement on the evils of employment discrimination provides no obvious answer to the question how to increase the wages of black workers or indeed of workers generally. ${ }^{6}$ Even the simple expedient of expanding legal remedies in discrimination cases has lost some of its obvious appeal: as the number of protected classes (sex, age, and disability) expands, the available resources to process claims in a sensible and orderly fashion diminish under the crushing administrative burdens. The backlog of unresolved cases increased from 49,000 to 73,000 during r994 alone.7 No longer is there any clear theme that easily allows individuals from different racial groups or walks of life to come together in pursuit of a common goal. There is no one civil rights movement anymore. The once-unified movement has fragmented into a bewildering array of specific pieces, each with its own distinctive focus on age, sex, race, disability, religion, or sexual orientation. Each of these organizations looks and acts more like a traditional special interest group and less like the vanguard of a universal moral movement capable of vanquishing all its foes with the loftiness of its purpose.

4 See, e.g., Richard Bernstein, Racial Discrimination or Righting Past Wrongs?, N.Y. TMES, July 13, 1994, at B8 (discussing Hopwood v. Texas, 2 I F.3d 603 (5th Cir. 1994), the lawsuit that challenged the affirmative action programs at the University of Texas).

5 See Abigail Thermstrom, Redistricting, in Black and White; By Any Name, It's a Quota, N.Y. TIMES, Dec. 7, 1994, at A23.

6 See, e.g., James Heckman \& J. Hoult Verkerke, Racial Disparity and Employment Discrimination Law: An Economic Perspective, 8 YALE L. \& PoL'Y Rev. 276, 297-98 (1990). For a more recent overview of the wage question, see Sylvia Nasar, Statistics Reveal Bulk of New Jobs Pay over Average, N.Y. TIMES, Oct. 17, 1994, at AI. The long-term trends are decidedly more problematic than the title of the piece suggests. Nasar observes that "there is evidence that hourly pay of at least the bottom half of the work force - those at the midpoint or below - continues to slip." Id. at $\mathrm{D}_{4}$. Black workers tend to be more heavily represented in this segment of the workforce. In addition, average real compensation increased by only $3.5 \%$ during the first half of the I9g0s, compared with increases of nearly $30 \%$ for the entire 1960 s and of nearly $15 \%$ for the entire r970s. See id. And for what it is worth, the position of white males in the workforce has deteriorated as of late as well. In the 19705 , about $80 \%$ of men between the ages of 22 and 58 were full time in the labor force; by the 1980 s that figure had dropped nine percentage points, at the same time that female participation in the labor force increased. See Sylvia Nasar, More Men in Prime of Life Spend Less Time Working, N.Y. TrMEs, Dec. I, 1994, at Ar.

7 See Peter T. Kilborn, Backlog of Cases is Overwhelming Jobs-Bias Agency, N.Y. TIMES, Nov. 26, 1994, at Ar. The article notes that many workers give up their complaints, because it now takes 19 months for an investigation; some individuals decide to initiate private suits after waiting the required six months before obtaining "right to sue" letters from the EEOC. See id. at AI, Aro. The article also notes that the EEOC is now reviewing its established policy, which favors the pursuit of individual grievances while avoiding the large class action lawsuits that rely heavily on statistical proof of disparate impact. Democrats have tended to favor the latter strategy; Republicans the former. See id. at Aro. 
The present disarray in the civil rights movement has led to a strong sense of nostalgia for the victories of the past generation. The civil rights agenda of the I940s, I950s, and perhaps even the I960s was clear and decisive: open up the polls to all voters; desegregate the schools; remove the ban on interracial marriage; curb private violence; end racial hatreds and divisions; and dismantle the entire apparatus of Jim Crow that dominated the South and stained the image of the nation as a whole. ${ }^{8}$ The totalitarian nature of the established institutions was plain for all to see; the strained efforts to justify Jim Crow laws and practices were grotesquely false. The use of public force and private initiative to overcome this entrenched set of social institutions is one of the great moral and political achievements of the twentieth century. It is natural, therefore, that people who have difficulty making sense of the current social landscape are drawn to refighting the war against Jim Crow.

Richard McAdams's Cooperation and Conflict: The Economics of Group Status Production and Race Discrimination ${ }^{9}$ is one of several recent papers that seek to justify the present operation of the civil rights laws with a backward-looking glance at the Jim Crow regime that dominated the South before $1964 .{ }^{10}$ But although McAdams gazes backward, his mission is forward-looking. I have taken the position that all civil rights laws that regulate behavior in private, competitive employment markets should be repealed.11 McAdams seeks to show that the full panoply of civil rights laws may be justified in a contemporary setting. He employs a novel set of arguments that would hardly have occurred to the original defenders of that legislation, who needed no subtle refinements to counter what they regarded as obvious injustices. McAdams's Article also has the broader purpose of employing the tools of law and economics, with their ostensibly conservative bias, for a decidedly liberal purpose. As applied to questions of race relations, he hopes to show that antidiscrimination laws may

8 For a discussion of the relevant issues, see Hugh D. Graham, The Civil Rights ERA: Origins and Development of National Policy, 1960-1972, at 3-5 (19g0); ANDREW Kull, The Color-Blind Constitution I-6 (I992); Michael I. Sovern, Legal Restraints on RAcial Discrmmination in Employment i-8 (I966); C. Vann Woodward, The Strange CaREER OF JMM CROW I-IO (3rd rev. ed. I974).

9 Richard H. McAdams, Cooperation and Conflict: The Economics of Group Status Production and Race Discrimination, I08 HARV. L. REV. 1003 (1995).

10 See, e.g., Andrew Koppelman, Why Discrimination Against Lesbians and Gay Men Is Sex Discrimination, 69 N.Y.U. L. REv. 197, 220-34 (1994); Cass R. Sunstein, The Anticaste Principle, 92 MrCH. L. REV. 24IO, 2434-36 (1994).

11 See Richard A. Erstein, Forbidden Grounds: The Case Against Employment DisCRIMINATION LAwS 9 (1992). McAdams is quite critical of my views on this subject and attacked them extensively in Richard H. McAdams, Epstein on His Own Grounds, 3 I SAN Diego L. REv. 24I, 241-42 (1994). For my rejoinder, see Richard A. Epstein, Standing Firm, on Forbidden Grounds, 3I SAN DIEgo L. REv, I, 5-10, I3, 46-48 (I994). 
be justified even under the standard efficiency criterion of the law and economics movement.

McAdams undertakes no modest task when he seeks to show that the dynamics of group behavior explain why the civil rights laws retain their importance even in social conditions vastly different from those that pertained before I964. His stated purpose is to make clear how private actors adopt hiring strategies without coercion that yield the unfortunate social outcomes that a well-crafted antidiscrimination law could prevent. In examining the soundness of this proposition, I exclude from consideration any unfortunate outcomes that are a result of the public or private use of force, deception, or even monopoly power. These practices involve different forms of coercion, all condemned under standard theories of tort or antitrust law, so there is little that is novel or surprising in a claim that a party endowed with these powers could bring about antisocial consequences. Nor do I think that it is particularly interesting to show that various techniques of social reinforcement can increase the effectiveness of coercive tactics so defined. Of course they can. The challenging task that McAdams has set for himself is to show that the ability to use status-production techniques has similar untoward consequences when these coercive factors are absent from the picture. One might think that this task would call for a close examination of employment practices in the post-I964 world in which diversity is a buzzword and affirmative action a common practice. The object of that inquiry would be to show that, beneath this pleasant veneer, covert practices, some corrupt and some unconscious, help to preserve an unacceptable pattern of racial discrimination.

Alternatively, McAdams could give a close examination of the determinants of wages and success. He might seek to show, for example, that blacks who have test scores equal to those of whites do not fare as well in the job market as do whites. Yet the evidence on the correlation between race and success in the job market is difficult to collect and to interpret. Initially, any investigator has to ask how pervasive programs for diversity and affirmative action could coexist with widespread covert patterns of discrimination in workplaces. Simple testimony that African-American workers believe themselves to be subject to discrimination is hardly dispositive on the question. The effort, therefore, to bolster these institutions must turn to some extent on complex statistical determinations that themselves defy easy interpretation. However, at least some of the evidence points in a direction that is inconsistent with the view that current labor markets pervasively discriminate against black workers. At least one suggestive (although highly controversial) study indicates that, for any given level of prerequisites and qualifications, black workers today fare better in the em- 
ployment derby than do white workers. ${ }^{12}$ And another, more econometrically minded study attributes much of the wage gap between black and white workers to their levels of education prior to entry into the work force. ${ }^{13}$ The question whether there is discrimination in contemporary labor markets has to be regarded as an empirical question on matters of direction as well as of extent. McAdams treats pervasive forms of employment discrimination as though the proposition were a self-evident truth.

McAdams does not approach matters in this straightforward fashion, however. Instead he veers off into a discussion of two distinct institutions, neither of which bears a close relationship to the topic at hand. First, he offers military parallels and analogies. Thus he starts with the famous speech of Henry V ("We few, we happy few ...") delivered to rally his troops before the battle of Agincourt; he then makes numerous references to the role of morale in military settings. Yet Henry's is no ordinary speech; his psychological ploy is to invite his men to leave although he knows that they must decline his invitation. But by the same token, the speech rings true for less heroic settings as well, because military cohesion is critical in all combat settings, even when the odds are not as skewed as they were at Agincourt.

More to my point, it is a very chancy business to analogize from military arrangements to other social systems, much less employment markets. Even the most casual observer instinctively recognizes that the military is a total institution - that is, one that seeks comprehen-

12 See Richard J. Herrnstein \& Charles Murray, The Bell Curve: Intelligence AND Class Structure In AMERICAN LIFE 488-92 (I994). Herrnstein and Murray's data may be summarized as follows: with IQ held constant, in 1990, the likelihood that a black person would reach a given professional level is about I.7 times the likelihood of a white person. See id. at 49 r. Parity between whites and blacks was achieved just prior to passage of the 1964 Civil Rights Act. See id. at $490 \mathrm{tbl}$. The disparity index rose rapidly in the four years that preceded the statute, leveled off at slightly more than 1.0 in the period between 1965 and 1970 , and spurted again after Griggs v. Duke Power Co., 401 U.S. 424 (197I), which made disparate impact and business necessity tests part of the working vocabulary of the civil rights law. See HERRNSTEIN \& MURRAY, supra, at 490 . The index for clerical work reached 1.0 only after the 1964 Act and has never been as favorable for blacks as that for professional work, which lends some support for the proposition that the civil rights laws tend to do more for upper-class blacks than for lower-class blacks. See id. Herrnstein and Murray's work might be questioned to the extent that it measures job success conditioned on IQ. Their findings would be strengthened, however, if black success in labor markets based on the Armed Forces Qualification Test, college boards, or other standardized tests showed the same result.

13 See Derek A. Neal \& William R. Johnson, The Role of Pre-Market Factors in Black-White Wage Differences 3 (Nov. 2I, 1994) (unpublished manuscript, on file with the Harvard Law School Library) ("While we find some evidence of labor market discrimination, we conclude that the disadvantages young black workers now face in the labor market arise mostly from the obstacles they faced as children in acquiring productive human capital. Our analysis suggests that public policy focus on the plight of black children in acquiring skills valued by the labor market."). 
sive regulation of the life of those who participate in it. ${ }^{14}$ As such, the military differs in important ways from ordinary employment markets, which respect spheres of worker privacy. Employment in the military is not at will, and soldiers are not allowed to join unions or to strike in the heat of battle. Although the ordinary employer will rarely recover damages and can never get specific performance when a soldier is in breach, the sovereign employer has a full arsenal of punishments, including death for desertion, that can be directed at the hapless soldier who violates the applicable legal norm. Matters of morale, important in all employment contexts, are a matter of life and death in the military. We may look with envy on the military's success in combatting racial discrimination, but we can hardly treat the military as a model from which we can draw powerful lessons about the operation of the competitive market.

Second, McAdams undertakes a close study of practices under Jim Crow, which like the military is a total institution, but which unlike the military has clearly totalitarian overtones. In that context his object is to offer a warning of how contemporary labor markets might operate if left unregulated by the civil rights laws. But Jim Crow is an odd focal point if the goal is to justify current antidiscrimination laws in political and social settings that are light years removed from the segregated South. ${ }^{15}$

Notwithstanding the evident limitations of his examples, McAdams proceeds in two stages to demonstrate why market discrimination he largely limits himself to discrimination against blacks - should be countered by a vigorous enforcement of antidiscrimination laws. First, by way of background, he draws on the rich literature from game theory to show that cooperation between individuals can often be improved by social norms and practices that use group membership and affiliation. One part of that strategy is to build up the individual selfesteem of group members, often by reducing the relative status of members of rival groups. ${ }^{16} \mathrm{Next}$, he applies this theory to race relations to show that the dominant white group historically has seized upon such practices to create a solidarity that has worked against the interest of excluded groups. ${ }^{17} \mathrm{He}$ claims that these unfortunate outcomes can only be countered by an effective antidiscrimination law that roots out these practices.18 In his view the status-production function of discrimination exerts so powerful an influence that it alone

14 See generally ERving GofFMAN, On the Characteristics of Total Institutions, in AsYLuMs, Essays on the Social Struation of Mental Patients and Other Inmates I, I-124 (1961) (describing the characteristics of total institutions).

15 For an account of the coercive behavior even in the absence of formal laws that mandate segregation in employment, see Epstein, cited above in note 11 , at 38-45.

16 See McAdams, supra note 9, at pp. IO2 I-23.

17 See id. at pp. 1049-53.

18 See id. at pp. 1074-83. 
is sufficient to maintain destructive racist practices long after the dismantling of the formal apparatus of Jim Crow. In the end he concludes, more cautiously than one might suppose, that the question whether civil rights laws should be retained is an empirical question that depends on whether the benefits outweigh the costs. ${ }^{19}$ But he claims that even this modest conclusion is in sharp conflict with my insistence on total repeal, a position that he asserts rests on some naïve hope that competitive market institutions already achieve a proper social result. 20

This brief response to McAdams tracks his two-part analysis. I shall begin by examining his general theory of human behavior. My point is not to deny the role that positive enforcement has in the governance of human behavior. Quite the opposite, knowing how informal norms work is critical to understanding all sorts of social arrangements, including employment contracts. ${ }^{21}$ But no fascination with positive methods of social reinforcement should blind us to the equally obvious point that these devices are most effective when used in tandem with coercive devices - including legal sanctions or threats of physical force - that are directed toward the same end.

My review of McAdams's general theory makes it possible to critique his view of race relations, both in the employment context and elsewhere. It is here that the shortcomings of the theory are most apparent. Individual and group interactions are an important part of social life, and status production is surely one activity in which all individuals engage. But there is no payoff to McAdams's proposed marriage between the status production function of social groups and his defense of the civil rights laws.

His chief mistakes are two. First, although he recognizes that all groups can resort to status-production techniques, he underestimates the effectiveness of these techniques as a counterweight to the activities of any dominant political group. As long as all parties have access to the same techniques, no one faction can maintain anything close to a monopoly-like position. A faction itself is not a monolith but a group of separate firms, and as with any ordinary business cartel, some members will defect from the dominant coalition if the economic opportunities present themselves. Meanwhile, outside a dominant coalition, other firms can happily expand their production even if the cartel holds firm. So even if one assumed (falsely) that ninety percent of the resources were in the hands of a dominant faction, that faction could maintain neither its cohesion nor its market share against the prospect of new entry. Having overestimated the stability of cartels,

19 See id. at p. 1082.

20 See, e.g., id. at 1074-78.

21 See EPSTEIN, supra note II, at 147-58 (describing the importance of informal enforcement mechanisms that pertain to contracts at will). 
McAdams then wrongly concludes that status production obviates the need for dominant groups to resort to public force and/or private violence to achieve their own political ends. The vital corrective role of new entrants into established markets is a point with more than theoretical interest. At the concrete level, the history of Jim Crow is squarely against him, as is much of the history of the civil rights movement itself. Coercion is always the main event; status production is the sideshow. ${ }^{22}$ The key social task is to minimize the level of public force in human affairs, which only the repeal and not the enforcement of the civil rights laws can achieve.

\section{Social Cooperation and Individual Behavior}

McAdams begins with the important truth that the standard individualistic explanations of human behavior do not account for the high level of cooperation observed between unrelated persons in various social settings. ${ }^{23}$ The economist's paradigmatic illustration of noncooperative individual behavior is the so-called prisoner's dilemma, in which each party in a social situation tends to defect from a mutually advantageous cooperative solution in search of private advantage. The irony is that these self-interested strategies lead to results that, in the end, are destructive to the aggregated interests of both players. Universal cooperation beats universal defection, so only the inability of the parties to coordinate their behavior from the outset induces them separately to take steps that lead to their common ruin. A standard argument for contractual obligations and for legislative intervention is that they tend to curb these destructive tendencies. Contracts allow individuals to take steps that would otherwise be privately costly by offering them remedies against breaches from the other side. ${ }^{24}$ And when contracts cannot be formed because of high transaction costs, the imposition of reciprocal obligations by legislation can provide similar forms of assurance. People will no longer fear their being unable to drill as they please for oil in a common pool, or cast their nets wide for fish, because they know that their rivals are also constrained by law from pumping out all the oil or capturing all the fish. The system of common restraints improves the outcome for all parties.

McAdams stresses the familiar point that the stark prisoner's dilemma model cannot satisfactorily explain why people do in fact cooperate with each other when they face no sanctions for defection. McAdams makes the correct and sensible point that the informal mechanisms of social practice, influence, and control usually counter

22 For a general philosophical treatment of the multiple meanings of coercion, see ALAN WERTHEIMER, COERCION 3-15 (1987). For my extended treatment of the many meanings of coercion, see Richard A. Epstein, Bargaining with the State 39-74 (1993).

23 See McAdams, supra note 9, at pp. roog-r3.

24 See Richard A. POSNER, Economic ANalysis of LAW §§ 3.9, 4.1 (4th ed. 1992). 
any private tendency to defect. McAdams notes, for example, that virtually all military operations have to rely on a spirit of affection, cooperation, and self-sacrifice. It may be in the interest of any single soldier to pick up and run, but if all soldiers followed that course of action, each would face a far greater risk of being killed, and the larger military objectives of the nation would be lost. Morale is critical to the effectiveness of any military force, which is why military training emphasizes team sports, cooperative action, and personal trust to create a general ethos of cooperation strong enough to survive the rigors of combat.

The importance of these social ties in human behavior is a theme that has not been ignored in the prior literature. Gary Becker, whose work on discrimination is much cited and discussed by McAdams, is also the author of a paper entitled $A$ Theory of Social Interactions, which seeks to explain how people behave when they perceive their well-being to be dependent on the well-being of others. ${ }^{25}$ Likewise, I have stressed the same theme in a paper called Altruism: Universal and Selective, in which I argue that altruism is directed toward specific individuals, but not toward all individuals. ${ }^{26}$ For our purposes, the refinements in the arguments matter less than one central observation: when people take into account the welfare of others in making decisions, they are less likely to act in a strictly egotistical fashion, less likely to contemplate defection from cooperative social solutions, and less likely to turn against those for whom they have a biological or social affinity. Any hurt one inflicts on these select people is also in part a form of self-inflicted harm. The point that comes through loud and clear in McAdams's paper is that altruism is usually selective, so that only some individuals are in the preferred class. The antisocial tendencies directed toward outsiders, therefore, are likely to increase, for now inflicting a harm on a known outsider is justified not only by the benefits that it brings to the actor, but also by the benefits that it brings to the larger class with which the actor identifies. Such is often the sordid logic of ethnic conflict, be it in Rwanda or in Bosnia. That same logic also applies to the old South, where ties of race and society were both strong.

There is no question, then, that models premised on narrowly selfinterested behavior do not fit with either the biological or social facts of human nature. Yet before one waxes too eloquently about the importance of noncoercive and nonpecuniary motivators such as altruism and status, one should recognize that the effective formation of group identity depends not only on the carrots of inspiration and coopera-

25 See Gary S. Becker, A Theory of Social Interactions, 82 J. PoL. EcoN. 1063, 1064-66, I090-9I (I974).

26 See Richard A. Epstein, Altruism: Universal and Selective, 67 Soc. SERv. Rev. 388, 390-92 (1993). 
tion, but also on the sticks of discipline and force. Military success does not depend solely on a spirit of camaraderie and honors for those who have fallen in battle. Harsh sanctions, including death, are imposed for desertion from the field of battle, for disobedience to the lawful commands of superior officers, and for collaboration with the enemy. ${ }^{27}$ Similarly, the firm that pays handsome bonuses for excellent performance also jealously guards its right to fire individuals who slack off in production and to punish criminally individuals who are caught taking money from the till.

Techniques of both positive and negative reinforcement are used simultaneously, because the economic principle of diminishing marginal returns applies to carrots as well as to sticks. Although one carrot may work wonders to boost morale, a second carrot may not work as well. At some point the problems of social organization will be far better addressed by the addition of the first stick instead of the twentieth carrot. ${ }^{28}$ No social organization shuns the use of positive reinforcement to obtain support. By the same token, all institutions must have some negative reinforcement to succeed. The problem institutions face is finding the optimal mix between the two; only rarely will an institution rely exclusively on positive reinforcement.

\section{Racial Discrimination as a Form of Social Cooperation}

\section{A. Three Models of Discrimination: Becker, McAdams, Epstein}

The first part of McAdams's thesis pays little attention to race per se, and rather lays out his analytical principles. The second part, however, purports to apply these general principles of social cooperation to the problem of racial discrimination. To make his case, McAdams de-

27 Soldiers can be punished for providing the enemy with any information beyond their name, rank, and serial number. See, e.g., United States v. Fleming, 7 C.M.A. 543, 549-54, 562 (1957), 23 C.M.R. 7, II-I5, 26 (affirming a soldier's sentence of life imprisonment for making communist propaganda recordings while held as a prisoner of war in Korea, despite the defendant's claims of coercion and distress).

28 A "coercive" ability to impose sanctions that reduce the utility of those who disobey the collective norms calls attention to the dual meanings associated with the term coercion. In one sense coercion only refers to techniques that are used to make other persons worse off in order to achieve some collateral end. Thus, a refusal to sell at $\$ 1.00$ could be regarded as coercive if the end is to elicit an offer of $\$ 2.00$. But coercion in this sense only refers to the intention to make someone else worse off. It does not carry with it the implication that the coercion involved should be stopped by the state. Otherwise neither seller nor buyer could bargain over price without running afoul of the legal rule, because both parties have used coercive behavior.

The second meaning of coercion involves far more than taking steps that diminish the satisfaction of another individual. The means are critical to this definition: force or the refusal to perform a preexisting obligation are the cardinal cases. A prohibition against these forms of coercion is sensible, because a system of bargaining works better if coercion in this strong sense is prohibited, even if coercion in the first sense to reach a contract price is routinely allowed. The intermediate case is that of hard bargaining by someone in a monopoly position, when some constraints on the process should be allowed. 
velops the contrast between Gary Becker's associational model of discrimination and his own status-production model of discrimination. According to McAdams, the associational model posits that "people who discriminate act as if they have a 'taste' for avoiding contact or association with members of other races." 29 Discrimination, in this view, turns on private likes and dislikes.

McAdams's alternative status model posits that the gains from discrimination lie not in the avoidance of association but in the exploitation of associations that inflict status losses on other groups to improve one's own self-esteem. His evidence comes from a variety of sources. Blacks were often hired in the segregated South to do domestic service, where they were in intimate association with the women and children of the household; white men (but not women) had sexual liaisons with black women, both by force and by stealth; and, most instructively, antimiscegenation laws prohibited lawful marriages between whites and blacks. These laws were not needed or intended to protect those whites who did not wish to marry blacks; rather "[t]he purpose was to prevent other whites from entering into such associations"30 to preserve the relative status differential between blacks and whites. For McAdams the lesson is that self-esteem feeds off of discrimination, so that "race discrimination may persist in the face of market competition [and that] race discrimination represents a market failure . . that may justify coercive restraint of private status 'confiscation'."31

It is important to disentangle fact from fancy in this portion of McAdams's analysis. First, according to Becker's theory of discrimination, we should not expect to see any complete separation between the races in ordinary employment settings. ${ }^{32}$ McAdams's reference to "avoiding contact or association" 33 makes it appear as though, according to the orthodox theory, separation were the final inevitable outgrowth of the system. In practice, however, different wages may be paid in integrated contexts as long as members of one group affirmatively want to work with members of the other group, who in turn would rather not work with the first group. Becker's point is that the market advantage lies with the victim of discrimination because,

29 McAdams, supra note 9, at pp. 1033-34 (quoting GARY BECKER, THE Economics of DisCRIMINATION 6 (2d ed. I97I)) ("If an individual has a 'taste for discrimination,' he must act as if he were willing to pay something, either directly or in the form of a reduced income, to be associated with some persons instead of others.").

To the extent that the preferences of those who discriminate are only "as if" preferences, they should be easily correctable. McAdams's position takes on more credibility when the point is made descriptive and not hypothetical - that is, to say that people do discriminate because they have these ingrained and invidious preferences.

$30 \mathrm{Id}$. at p. I039.

31 Id. at p. I036.

32 See Gary Becker, The Economics of Discrimination 48-49 (2d ed. i97 I).

33 McAdams, supra note 9 , at p. 1034 . 
viewed as a whole, his wage demands are lower than those of his snootier rival. In the end, therefore, the taste for discrimination will be a liability and not an asset - unless one can show that this preference provides some offsetting benefit that once again converts it into a net asset. ${ }^{34}$

In addition, the Becker model does not make any strong prediction that separation between races will be the norm. Rather, the precise result is difficult to predict, because much will depend on the sentiments of the various workers and the number and distribution of firms within the industry. Becker assumes that whites do not wish to associate with blacks but that blacks do wish to associate with whites. ${ }^{35}$ His stylized assumption is a useful means of exposition, but it hardly presents an accurate reflection of the current employment situation (however plausible an account it might have been in 1957 when Becker's book was first published). Today, the respectable calls for separation seem to come more often from blacks than from whites. ${ }^{36}$ To make matters only more complicated, the intensity of the demand for separation is not uniform within or across races. But it all hardly matters. As long as the process is open, and choice is left available, whatever level of mixing and separation emerges should be greeted with approval, not suspicion. ${ }^{37}$ We do not possess theories of justice strong enough to allow us to condemn outcomes as unfair when the processes used to reach them are legitimate.

Once again it is important to note the limitations of the system: the Becker model only deals with behavior under a purely competitive system - indeed one that operates without the usual frictions associated with contracting in market contexts. In addition, the model does not apply to cases in which force may be used to bar rivals from the market. Once whites have the added power to keep blacks from leaving the South, the model would no longer apply, for whites could then adopt strategies to exploit the vulnerable position of blacks. But that outcome is not possible in a market setting in which the exit option constrains the behavior of the dominant group. If McAdams wishes to explain how invidious segregation can prosper in market settings, he cannot rely on behaviors in nonmarket settings, like the Jim Crow South, to make his basic point. He must show how self-interested market behavior in and of itself is capable of leading to socially undesirable results.

34 See BECKER, supra note 32, at 39-53.

35 See id. at 3I-32.

36 See Steven A. Holmes, N.A.A.C.P. Leader, Ousted by Board, Hints He Will Sue, N.Y. TMmes, Aug. 2r, 1994, at AI, B7 (reporting that some NAACP officials believed Mr. Chavis was moving the organization into a separatist posture).

37 See Robert Nozick, ANarchy, State, Utopia 168, 170-74 (1974) (noting that "patterned principles" of justification constantly require the state to reassign entitlements otherwise obtained through voluntary exchanges). 
In Forbidden Grounds, I examined the behavior of firms and individuals in competitive settings, as did Becker. In contrast to Becker, however, I assumed that competition referred to a situation in which many employers were bidding for the services of many employees. Unlike Becker, I assumed that these markets were characterized by various sorts of frictions that made contracting tricky even within the competitive framework. This alternative model is, I think, more realistic than the rather stylized market postulated by Becker. The fuller model also raises a possibility that Becker discounted, namely that some forms of racial discrimination could persist by allowing individual firms to prosper. Competition thus need not eradicate all forms of discrimination, but the forms of discrimination that survived could be regarded as "rational" because of their useful social consequences. ${ }^{38}$

The concrete benefits of continued racial discrimination come from two sources. First, firms provide various forms of limited public goods for their workers. Any office has to have conventions about dress, decor, and music that cover all its workers. These conventions bind all group members even though outsiders are excluded. They thus create limited public goods that are easier to supply as the homogeneity in the tastes of group members increases. To the extent that these tastes are correlated with membership in various racial, ethnic, and religious groups, firms that cater to these preferences could well have higher production at lower costs and hence would prosper in a market setting.

Second, the enforcement of the terms of any employment contract through legal mechanisms is both costly and imperfect. To compensate, firms have to rely on informal social sanctions to keep affairs running on an even keel. If some forms of discrimination will make it easier to select these firm-specific public goods, or to enforce these employment contracts by informal means, racial discrimination will survive even in open and competitive markets. Yet by the same token, discrimination will not lead to wage discrimination or to the disadvantage of members of any racial group. The point is that market separation, unlike political separation, does not go hand in hand with the personal domination that McAdams fears. The advantages of separation are gained not only by whites, but also by blacks and by other ethnic groups as well. Accordingly, some forms of voluntary discrimination lead to uniformly higher wages and to uniformly higher levels of worker satisfaction, hardly the making of a social crisis. ${ }^{39}$ In addition, it seems clear that these strategies of separation do not make sense for all firms, even if firms seek to cater slavishly to the racial preferences of their customer base. In some cases, these market preferences are likely to be insignificant. Thus, there is little reason to ex-

38 See EPSTEN, supra note II, at 59.

39 See id. at $45-46$. 
pect discrimination in those businesses in which there is little customer contact. This condition is satisfied, for example, in all sorts of manufacturing and production jobs. But even in consumer markets, one would have to presuppose an astonishing uniformity of preference to assume (especially in an age in which there is widespread political support for the principles of diversity) that whites so prefer to deal with each other that they will take active steps to shut qualified blacks out of positions of influence and power. A moment's glance at the advertisements in the New York Times or the Chronicle of Higher Education should persuade even the most hardened skeptic of the explicit and enduring commitment of elite institutions to hiring minority applicants. White-only associational preferences do not play a prominent role in today's society; the movement in favor of diversity and multiculturalism has steamrollered its opposition, which is couched in color-blind terms.

It therefore seems odd in the current setting to stress that status production promotes discrimination against blacks; in most cases status production is used to promote blacks' interests. At best, one can say that McAdams shows that the status-production mechanism might enforce discrimination in certain limited areas. But even for this limited task, he has to make two additional points to clinch his argument: that the mechanism he identifies is more important than the market mechanisms I identified in Forbidden Grounds; ${ }^{40}$ and that even if the role of status production is important, status production leads to employment outcomes that the state should prevent. I think that his first point is at best dubious and that his second is clearly wrong.

\section{B. Libertarian and Statist Visions of the Law}

The larger mistake of McAdams's argument is that he does not link Becker's analysis to a more systematic account of the legal regime in which private actors behave. Many of his attacks - indeed too many - are directed toward slaying the Jim Crow dragon, which is an odd target indeed if his objection is to hiring strategies that are available to all in competitive markets. Why use - and use constantly - an example that is so far removed from the market institutions that are the ostensible focus of examination? Indeed, the constant references to Jim Crow can only be designed to create the appearance of guilt by association. But ironically that charge is one that has some force when directed toward McAdams's argument. For while his motives are far more laudable than those of Jim Crow, he is all too willing to use government coercion to achieve a desired social end, an undertaking that a cautious libertarian would scrupulously seek to avoid.

40 See supra p. Iogr. 
To see the coercive end-state vision of the modern civil rights laws, it is instructive to look at the structure of Title VII, which McAdams ignores:

It shall be an unlawful employment practice for an employer: (I) to fail or refuse to hire or to discharge any individual, or otherwise to discriminate against any individual with respect to his compensation, terms or conditions, or privileges of employment, because of such individual's race, color, religion, sex, or national origin . ... ${ }^{41}$

Even if Title VII were repealed tomorrow, the libertarian prohibitions on force and fraud in the employment market, as elsewhere, would remain. The repeal of Title VII would not give any individual the powers that privileged persons routinely enjoyed under Jim Crow. Private violence by anyone against anyone else would still be sternly prohibited. In this context, an antidiscrimination norm does apply: all persons are bound by that constraint, regardless of race, creed, or color. And of course, nothing in this libertarian position allows some privileged persons to determine other people's trading (or marriage) partners, so the antimiscegenation laws are out as well. Jim Crow presented no world that I would care to defend, but rather was a sick, statist society that gave official vent to the worst and meanest prejudices of all individuals. The very libertarian and market-based theories that McAdams wishes to discredit reject Klan activities and various forms of violence and abuse.

To compound the confusion, McAdams attacks private discrimination as though it were part and parcel of a larger collection of public racist practices. He makes it appear that only his theory can respond to actions driven by hostile racial motives. In fact, some of these acts are illegal under theories that care little about motive and much about aggressive, fraudulent, or monopolistic conduct. "Discrimination and racist behavior generally are processes by which one racial group seeks to produce esteem for itself by lowering the status of another group."42 This "race-neutral" version of the proposition makes it appear as though all racial groups have equal resort to the same set of techniques, without explaining why any dominant group could obtain some systematic advantage from these techniques. But the success of the technique depends upon the available tools, which are not evenly distributed when one group controls the levers of power, as was the case under Jim Crow. It is critical to pay special attention to the coercive means that were used in that setting and to ask why any members of a subordinate group would stick around and take abuse if they were free to work elsewhere. Indeed, it is only within the context of a Jim Crow setting that it is proper to invoke the work of George Akerlof to show that a caste system may work to punish those who

4142 U.S.C. $\$ 2000 \mathrm{e}-2$ (a) (1988).

42 McAdams, supra note 9, at p. 1044. 
flaunt its taboos.43 McAdams's attack is well aimed if his desire is to criticize large statist systems of social control under Jim Crow; his argument, however, is beside the point in any contemporary defense of Title VII's mischievous interference with private competitive markets, which are decidedly non-caste structures. ${ }^{44}$ Our dispute is not over whether Jim Crow is just - we both agree that it isn't. The question is whether any dominant social group could maintain its social dominance in a modern setting solely by choosing its trading partners and the terms and conditions on which they trade.

\section{Can Status Deprivation Survive Without State Control or Private Violence?}

The history of Jim Crow raises a second issue on which I differ sharply from my critics. ${ }^{45} \mathrm{My}$ basic position in Forbidden Grounds was that the entire apparatus of Jim Crow was supported by three pillars: social and cultural norms, public force, and private violence. ${ }^{46}$ McAdams is careful not to claim that Jim Crow shunned the use of private and public violence. He recognizes that violence was often used. ${ }^{47}$ But he claims that his status-production theory shows that invidious forms of discrimination could persist in other settings without the coercion on which Jim Crow so heavily depended. ${ }^{48}$

Yet once again McAdams does not point to any modern system that shuns the use of force and is able to maintain anything similar to the caste-like structure of Jim Crow. Nor can we assume that status production could have maintained Jim Crow without a handsome boost from the use of force. Any social and cultural norms, however embedded, would have failed the task of maintaining segregation, because they could not forestall the threat of entry by outsiders and exit by locals. If whites and blacks from the North could move to the South and offer positions to blacks, why would domestic servants have chosen to remain in households that demeaned and degraded them? The presence of new alternatives would induce the prior employers to

43 "It is the essence of a caste-system, Akerlof says, that 'any transaction that breaks the caste taboos changes the subsequent behavior of uninvolved parties' who may act to punish the castebreaker." McAdams, supra note 9, at pp. 1064-65.

44 For two very different views of the question of caste in contemporary settings, see Sunstein, cited above in note Io, at $24 \mathrm{II}-13$.

45 See, e.g., J. Hoult Verkerke, Free To Search, I05 HARv. L. REv. 2080, 2089-94 (1992) (reviewing Epsten, supra note II); Ian Ayres, Price and Prejudice, New Republic, July 6, I992, at 30,31 (same).

46 See EPSTEIN, supra note II, at 93-97.

47 See McAdams, supra note 9, at p. 1052 ("Thus, when black successes threatened white status, whites used violence to defend their position and keep blacks in their place."). "The only exception that I take to this sentence is the word "status." Whites could and did use violence to defend many of their interests that were threatened by blacks and not only the status interests that McAdams discusses at length.

48 See id. at p. 1055 . 
mend their ways, or employees would seek more favorable circumstances. If only cultural norms were involved, employees could collectively thumb their noses at their prior employers and could entice other black workers to follow their lead. Black solidarity could help facilitate their break from traditional discriminatory patterns without fear of intimidation from racist sheriffs or vigilante bands.

In this connection it is useful to look at Heckman and Payner's study on the South Carolina textile mills. ${ }^{49}$ Their data are remarkable for revealing the consistently low percentage of blacks who worked in the various textile mills between I9ro and 1965.50 If that low percentage of blacks were found only within a single firm, the outcome could be attributed to the segregationist or racist policy of its owner or of its white employees. Yet the consistent figures are industry-wide: can we really believe that, for a fifty-five year period, no one thought that there were any gains to be made by coming into a market where skilled black labor was largely untapped? By I965, the percentage of black workers in previously white firms started to increase ${ }^{51}$ due to the federal government's protection of firms that hired black labor from physical aggression. There was no magical or sudden transformation in social attitudes. Why then did status production lose its power? Only because the coercive props were knocked out from under it. Similar results occurred in the trucking industry. The passage of the r964 Civil Rights Act did little to increase black representation among drivers, but a much more robust response resulted when reform legislation relaxed the preexisting barriers to entry into the field. 52

By appealing to the role of imperfect information and high transaction costs, McAdams minimizes the enormous influence that entry and exit can have on firm behavior. He thus argues that "assuming that there are any parties who will boycott 'innovators' (those who violate discriminatory norms), and that one cannot costlessly distinguish boycotters from nonboycotters, the innovators necessarily incur higher search costs in finding trading partners."53 "Market failures" of this sort are a dime a dozen and worth precisely that. McAdams's analysis assumes that boycotters keep their intentions secret, but normally they proclaim their goals loudly to the world. The Arabs did not conceal their boycott of firms that did business with the Israelis. Labor unions

49 See James J. Heckman \& Brook S. Payner, Determining the Impact of Federal Antidiscrimination Policy on the Economic Status of Blacks: A Study of South Carolina, 79 AM. ECoN. REV. 138, 140-45 (1989). I have commented on this study at length in EPSTEIN, cited above in note Ir, at 244-54; and Epstein, cited above in note II, at 43-44.

50 See Heckman \& Payner, supra note 49 , at $140-43$.

s1 See id.

52 See John S. Heywood \& James H. Peoples, Deregulation and the Prevalence of Black Truck Drivers, 37 J.L. \& ECON. I33, I33-35 (I994).

53 McAdams, supra note 9, at p. 1066. 
do not keep their secondary boycotts hidden. The Montgomery boycott of the I950s was not a well-kept secret. People who comply with a boycott may keep their compliance a secret to avoid retaliation from the other side, but the boycotters only make their case by going public and getting third parties to join with them. To be sure, all boycotters run the risk of retaliation, but what they gain in exchange is visibility and solidarity, the very status-production goods that McAdams emphasizes.

McAdams also overlooks the counter-strategies that an open market offers to those who wish to do business with these innovators. They can identify themselves publicly (without fear of coercive retaliation) and thus reduce the costs that innovators incur in finding trading partners. Of course, they can also boycott the boycotters, who therefore have to pay a heavy economic price to pursue a strategy that has little likelihood of success. I see no reason to suppose that mere collective refusals to deal could have stopped the massive entry into the South, and of course these tactics could have done absolutely nothing to stop the mass exodus from the South that took place during the first half of this century. ${ }^{54}$ What good does it do to refuse to deal with those prospective employees who are already out the door?

Yet it should never be supposed that launching a boycott is itself a riskless procedure. It is one thing to invoke the strategy and quite another to make it work over the long haul, as evidenced by the welldocumented frustrations of the pure boycotter. One major unresolved question of labor relations is the extent to which the activities of labor picketers can be regulated or enjoined on the ground that they involve an implicit (but very evident) threat of the use of force. The history of labor law shows that the common law, the Constitution, and the labor statutes all have struggled futilely to sort out protected speech from unprotected force. 55 During the past Term, the Supreme Court faced the same conflict over free speech in connection with the picketing of abortion clinics by Operation Rescue. ${ }^{56}$ All boycotters face (but need not yield to) the temptation to use force, because they know that the more peaceful means of persuasion may well fail.

The same point can be brought home by looking at the black boycott of white merchants in Claiborne County, Mississippi. The boycott gave rise to extensive litigation, first in the Mississippi courts, ${ }^{57}$ and then in the United States Supreme Court.58 From I966 to I972,

54 For a discussion of the level of black migration from the South to Chicago, see Nicholas lemann, The Promised Land: The Great Black Migration and How It Changed AMERICA I6 (I99I).

55 See, e.g., Vegelahn v. Gunter, 44 N.E. 1077, I077 (Mass. I896).

56 See Madsen v. Women's Health Ctr., Inc., II4 S. Ct. 2516, 2526, 2529 (I994).

57 See NAACP v. Claiborne Hardware Co., 393 So. 2d 1290, 1293 (Miss. 1980), rev'd, 458 U.S. 886 (I982).

58 See NAACP v. Claiborne Hardware Co., 458 U.S. $886,888-89$, gII (I982). 
blacks conducted a boycott of white merchants in Claiborne County, until the elected white officials of the county met their demands for integration of the county police force and other county offices. ${ }^{59}$ The boycott prompted a suit for tortious interference with business relations, and a Mississippi chancellor imposed a judgment in excess of a million dollars jointly and severally on all the participants in the boycott. The damage judgment was then backed up by a permanent injunction against the continuation of certain boycott practices. ${ }^{60}$ In reversing the judgment of the Mississippi courts, Justice Stevens, writing for the Court, did not deny that the black boycotters used both violence and vilification to deter black defection. ${ }^{61}$ Quite the opposite: in my view, his opinion dubiously allowed the First Amendment to shield the boycotters from the consequences of their own violence. Why would the boycotters have had to resort to violence if vilification alone could prevent defection from the grand coalition?

What was true of the NAACP in Claiborne Hardware was true as well in the old South, in which the combination of public and private actions restricted the actions of anyone who wished to deviate from the dominant practices. No one denies that ostracism and contempt were part of the overall strategy of social control, but always in tandem with the public abuse of administrative power and the selective use of private violence. Professor Kenneth Karst, no sympathizer of my position, supports this thesis in his pre-revisionist account of Jim Crow:

59 See id. at 898-900.

60 See Claibome Hardware, 393 So. $2 \mathrm{~d}$ at 1293.

61 Although Justice Stevens stated that "[t]he First Amendment does not protect violence," he went on to observe that, when violence occurs ${ }^{{ }^{i}}$ in the context of constitutionally protected activity," the presence of protected activity partially insulates some violent activities from legal sanction. Claiborne Hardware, 458 U.S. at 916.

According to Justice Stevens:

The opinion of the Mississippi Supreme Court itself demonstrates that all business losses were not proximately caused by the violence and threats of violence found to be present. The court stated that "coercion, intimidation, and threats" formed "part of the boycott activity" and "contributed to its almost complete success." The court broadly asserted without differentiation - that "[i]ntimidation, threats, social ostracism, vilification, and traduction'" were devices used by the defendants to effectuate the boycott. The court repeated the chancellor's finding that "the volition of many black persons was overcome out of sheer fear." These findings are inconsistent with the court's imposition of all damages "resulting from the boycott." To the extent that the court's judgment rests on the ground that "many" black citizens were "intimidated" by "threats" of "social ostracism, vilification, and traduction," it is flatly inconsistent with the First Amendment. The ambiguous findings of the Mississippi Supreme Court are inadequate to assure the "precision of regulation" demanded by that constitutional provision.

Id. at 92 I (footnotes omitted).

Not the least of the ironies of Justice Stevens's opinion is that it appears to invalidate the Civil Rights Act insofar as the Act is justified as a means to control "social ostracism, vilification, and traduction." All of these behaviors are protected under the First Amendment for whites as well as for blacks. 
Jim Crow illustrates the main technique of nativist domination: the enforced separation of members of the subordinate cultural group from a wide range of public and private institutions that, in the aggregate, constitute "society." Racial segregation in the American South was the successor to slavery and the Black Codes, both of which had been decisively made unlawful by congressional legislation and the Civil War amendments. In this historical context it is easy to see Jim Crow for what it was: a thoroughgoing program designed to maintain blacks as a group in the position of a subordinate racial caste by means of a systematic denial of belonging. Jim Crow laws extended from disenfranchisement to prohibitions on interracial marriage and imposed racial segregation everywhere: schools, courtrooms, buses, restaurants - indeed, all places where people of both races otherwise might interact in public. Private racial discrimination also played an important role in maintaining the caste system, producing segregation in housing, employment, and public accommodations, and leaving a legacy that, even today, remains only partially remedied. Lynching was the system's ultimate weapon, and it was by no means a wholly private enterprise. ${ }^{62}$

This use of force, both public and private, was often directed against blacks who might have chosen to leave the old South - enticement of labor was a crime in many states. ${ }^{63}$ McAdams is right about one point: if the sole goal were dissociation, the enthusiasts of Jim Crow should have paid for the tickets. But he is wrong about why dissociation was not their objective. They did not seek happiness from a market economy in which they were equal players: they sought still greater gains from their local dominance backed by state force and private violence, which could only work so long as the victims were kept close to home. No libertarian world here, so McAdams's account adds nothing to condemnations that are already in place.

\section{Status Production for All}

McAdams fails to develop fully the point that any group can seek to build group solidarity by appealing to group mission and group identity. More specifically, McAdams cites the work of Dennis Chong ${ }^{64}$ to the effect that a "non-material concern for reputation served as a motivator in civil rights activities like the freedom rides, the Montgomery bus boycott, the Selma voting drive, and the Greens-

62 Kenneth L. Karst, Paths to Belonging: The Constitution and Cultural Identity, 64 N.C. L. REV. 303, 32I (I986) (citations omitted).

63 See William Cohen, Negro Involuntary Servitude in the South, 1865-1940: A Preliminary Analysis, 42 J. S. Hist. 31, 33-36 (1976).

64 Dennis Chong, Collective Action and the Civil Rights Movement (r99i). Chong's work is discussed in McAdams, cited above in note 9, at notes 52-55 and accompanying text. 
boro lunch counter sit-in."65 No one who has lived through the I950s and I 960 s would want to deny the power of the rhetoric used in opposition to Jim Crow. It was the opponents, not the supporters, of Jim Crow who sang "We shall overcome," who organized the marches, the prayer meetings, the fund raising drives, the voter registration campaigns, the pamphlets, and the support groups to keep their mission going in the face of racial hostility. It was Rosa Parks who inspired and Martin Luther King, Jr. who organized the boycotts of the bus companies that maintained segregated seating. It was not the white racists who borrowed the do-or-die rhetoric of Henry $V$; it was their outmanned, politically marginalized, and physically vulnerable opponents. In fact, the rather pathetic propaganda counter-efforts by the entrenched but morally bankrupt majority look feeble in comparison.

But once again details matter. When did the opposition resort to these techniques to attack Jim Crow? The above list of stirring events all took place after I954. That is, they took place after the decision in Brown v. Board of Education ${ }^{66}$ showed that the might of the federal government would align itself against the forces of Jim Crow. Before that time what group would have wanted to face the unconstrained fury of southern justice and private revenge? It was only when some external - read "federal" - force began to neutralize the public and private violence of the Jim Crow South that voluntary organizations could speak out on such matters as voting and integration of lunch counters or buses. Before that time no techniques of status production emboldened fair-minded white southerners to speak out and march against the practices of Jim Crow. The risks of force and retaliation were far too great. And the same was true for southern blacks.

The lesson seems clear for the modern-day issues that McAdams addresses. State coercion and private violence are no longer bars to black aspirations in the labor markets. In this environment, the status-production techniques are not only open to the small fraction of whites who still cling to the old ideals of Jim Crow, but also to individuals of all races who reject such teachings. White groups that support integration or affirmative action can use status-production techniques, as can the same black groups that fought so hard against Jim Crow. Why, then, does the state have to give additional assistance to the large array of groups that have adopted status-production techniques to promote the antidiscrimination or affirmative action goals that they champion? These new groups may not be able to bring everyone along with them, but certainly they would not be snuffed out or rendered powerless if the civil rights laws were repealed, so

65 McAdams, supra note 9, at p. Ior8 n.54. For an analysis of the rhetorical style of the civil rights movement, see Gerald N. Rosenberg, The Hollow Hope: Can CovrTs Bring About Soctal Change? 39-4I (I99i).

66347 U.S. 483 (1954). 
long as the prohibition against the misuse of public and private force is scrupulously enforced.

McAdams, however, does not sufficiently explore the extent to which these status-production mechanisms are available today to groups of all races and persuasions. Instead, he tends to give these devices greater weight in the hands of bigots. "[E]conomic analysis of discrimination strikes many non-economists as barren because it fails to acknowledge the full benefit to its practitioners .... [That benefit is that] whites gain status by discriminating against blacks."67 But once again he stops the analysis too quickly, for there is no particular reason to assume that (some) whites have a built-in advantage in status production. Nor should it be supposed that privileged whites are better able to practice discrimination because of their higher social status. People with such elevated status make obvious targets for ridicule and contempt: after all, what possible reason save systematic social corruption could account for such dubious characters' occupying places at the top of the social hierarchy? Conversely, oftentimes the bitterest resentment toward blacks comes from poor whites who think that their own low-status position is evidence that they have been passed over in the endless set of social reforms that have worked against their interests. Resentments can be widespread, and anyone who is resentful can take out his anger by words and deeds of discrimination.

McAdams's argument also fails even if we confine our attention to status production as a tool in overt political struggles. In these charged settings, the techniques of status production make the opposition to race discrimination more tenacious, for the same general reason, and for a better cause. Recall that the post-I964 boycott in Claiborme Hardware started because of the cohesive social unity of most blacks within the county, who were held together by church groups and the NAACP. But as time wore on, the boycotters systematically resorted to threats of force and intimidation to prevent outsiders or defectors from upsetting their plans. ${ }^{68}$ If McAdams were correct about the power of status production, he could not explain why the boycott organizers resorted to these strong-arm tactics between 1966 and 1972 when they were no longer an insulated minority. Yet a more dispassionate explanation is not hard to find. The boycotters took these steps because they were necessary to the success of the venture, and they were successful because the use of force was ultimately tolerated by the transformed legal order in the post-I964 South.

But questions still remain. Can the civil rights movement today organize itself as effectively when force, fraud, and monopoly cannot

67 McAdams, supra note 9, at pp. 1076-77.

68 See NAACP v. Claiborne Hardware Co., 393 So. 2d 1290, 1297 (Miss. I980), rev'd, 458 U.S. 886 (1982). 
be raised up against it? Or is some moderate adversity needed to keep the movement cohesive? The question is harder to answer than it first appears. On the one hand, the costs of association clearly are far lower; therefore, if the benefits were constant, we should expect to see a larger number of groups opposed to discrimination, who use these status-production techniques to organize. On the other hand, the benefits from such organization shrink, because the most important targets have already been taken, which leaves the next stage of the civil rights agenda far more open to means-ends debates than the agenda that preceded it. It is difficult to see such esteem-producing moral convictions' arising out of the redistributive game that the civil rights laws have fostered.

\section{E. The Contemporary Risks of Adopting a Status-Deprivation Model}

There is little reason to believe that an appreciation of the statusproduction model requires an abandonment or modification of competitive labor markets as contemplated by the civil rights laws. But it is also important to note that there are grave risks in any effort to create a government monopoly on matters of hiring, as the Civil Rights Act does. Government power cannot be doled out in perfect measure. Even if status-production functions should be countered by an antidiscrimination ordinance, it is highly unlikely that the army of bureaucrats and lawyers charged with the enforcement of the statute will confine its operation to the laudable purposes that justify its use.

Rather, the far greater risk is that the new statists will emulate some of the worst characteristics of the old Jim Crow regime. The original civil rights statute may have been misguided in its aim, but at least it was universal in its aspiration. It protected all individuals. Yet almost without reflection, the Supreme Court has read the statute to create protected classes against whom discrimination counts, and, by implication, unprotected classes against whom discrimination can be practiced with impunity. By a few deft judicial decisions, a universal statute has become a partisan regime that uses public force to encourage some forms of discrimination while banning others. ${ }^{69}$ I cannot

69 This is the combined effect of three great antidiscrimination cases of the 197os. Griggs v. Duke Power Co., 40I U.S. 424 (197I), first made it clear that proof of intent was not required when discriminatory consequences resulted. See id. at 432. McDonnell Douglas Corp. v. Green, 4 II U.S. 792 (1973), made it clear that disparate treatment under the Civil Rights Act applied only to protected classes. See id. at 802 . The transformation was made without note or fanfare. The key passage reads as follows:

The complainant in a Title VII trial must carry the initial burden under the statute of establishing a prima facie case of racial discrimination. This may be done by showing (i) that he belongs to a racial minority; (ii) that he applied and was qualified for a job for which an employer was seeking applicants; (iii) that despite his qualifications, he was rejected; and (iv) that, after his rejection, the position remained open and the employer continued to seek applicants from persons of complainant's qualifications. 
think of a single good argument that would allow the statute to ban whatever affirmative action or diversity program a private firm wishes to adopt, however shallow the firm's reasons or asocial its consequences. But I also cannot think of a single good argument to build formal distinctions between races into the fabric of the law, either by initial statutory design or by judicial machinations such as the designation of some groups as "protected classes." Nor can I understand why government officials should countenance separation only by blacks, or regulate integrated workforces by insisting that any deviation from some predetermined goal or quota subjects a firm to costly examination and potentially serious penalties. Is this really the appropriate response to the racial snubs and slights of private individuals? Or do we have to recognize that the employment discrimination laws reach only a tiny fraction of the antisocial behavior that McAdams identifies, although these laws have an adverse impact on the operations of tens of thousands of lawful businesses in the United States? It may be an empirical question whether we need to maintain the employment discrimination laws once the question of status production is taken into account. But nothing suggests that this empirical question is a close one.

The time has come to stop beating the dead horse of Jim Crow. The issues of race relations in the United States today are far more heavily influenced by the massive commitment to the Civil Rights Acts of the last thirty years, and the failures of the current situation cannot be laid at the doorstep of a set of odious practices that have long since ceased to control our social lives. The blunt truth is that the Civil Rights Acts have not and cannot increase economic prosperity and racial harmony. The Civil Rights Acts have instead created a drag on labor markets and compelled "good" discrimination whose consequences are often as invidious as those of the forms of discrimination that they attack. Our best hope for the future is to remove from employment markets all the shackles that have been so assiduously built up since 1964 and to stop pretending that ostensibly benevolent forms of labor regulation can succeed although bad forms have

Id. at 802 (emphasis added). Note that the initial sentence applies to all complainants. Yet under the first condition, only members of a "racial minority" may claim the benefit of the test. Under a colorblind interpretation, any qualified person who is passed over should be able to take advantage of this test, especially if the person ultimately hired was of a different race. United Steelworkers v. Weber, 443 U.S. 193 (1979), completed the task by allowing voluntary race-conscious affirmative action. See id. at 207-08. Weber acted as though the earlier decisions in Griggs and McDonnell Douglas operated in a different moral universe. But in practice the ex ante incentives on employers are driven by the intersection of the three decisions. In following a colorblind strategy, an employer risks being held liable under a disparate impact theory, even if its hiring decision were not influenced by any impermissible racial motive. In following an affirmative action strategy, an employer avoids this powerful form of Title VII liability but runs little or no danger of liability to those disappointed employees or applicants who are not members of a protected class. The tilt induced by these asymmetrical payoffs seems clear. 
already failed. Professor McAdams's attempt to salvage the Civil Rights Acts by an appeal to sophisticated but incomplete conceptions of status production is a failure. And so are the Civil Rights Acts whose continued existence he vainly seeks to justify. 